\title{
THE ALLEGORY OF THE CHURCH
}

\author{
Romanesque Portals
}

and Their Verse Inscriptions 
This page intentionally left blank 


\section{THE ALLEGORY \\ OF THE CHURGH}

\section{Romanesque Portals \\ and Their Verse Inscriptions}

Calvin B. Kendall

with photographs by Ralph Lieberman

UNIVERSITY OF TORONTO PRESS

Toronto Buffalo London 
www.utppublishing.com

(c) University of Toronto Press Incorporated 1998

Toronto Buffalo London

Printed in Canada

ISBN 0-8020-4262-7

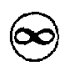

Printed on acid-free paper

\section{Canadian Cataloguing in Publication Data}

Kendall, Calvin B.

The allegory of the church : romanesque portals and their verse inscriptions

Includes bibliographical references and index.

ISBN 0-8020-4262-7

1. Doorways, Romanesque - Europe. 2. Church doorways-Europe.

3. Architectural inscriptions - Europe. 4. Inscriptions, Latin-Europe.

5. Christian art and symbolism - Europe. I. Title.

NA4950.K45 $1998 \quad 726.5^{\prime} 1822^{\prime}$ O9409021 $\quad$ C97-932536-6

University of Toronto Press acknowledges the financial assistance to its publishing program of the Canada Council for the Arts and the Ontario Arts Council. 
To Eleanor 
This page intentionally left blank 